\title{
The Legislative and Institutional Framework for War-Affected Land Rights in Iraq: Up to the Task Post-ISIS?
}

\author{
Jon D. Unruh \\ McGill University
}

\begin{abstract}
Land and property rights in Iraq have been highlighted as a fundamentally important component of recovery, particularly subsequent to the ISIS conflict. The return of 3.3 million internally displaced persons (IDPs) due to the ISIS occupation and conflict are encountering claimants who were dislocated from previous wars and expropriations. This results in numerous and complicated land conflicts that if not dealt with in a proactive way, will contribute to the country's instability. Of primary importance in this regard is an ongoing discussion in government and the international community which focuses on a central question - are the current laws and institutions in Iraq, made for stable socio-political settings, able to manage the large-scale land and property problems emerging and ongoing in the country? This article considers this question by examining and critiquing the current legislative and institutional framework in Iraq in the context of the historical-to-present trajectories of land rights problems and development of land and property laws and institutions.
\end{abstract}

Keywords: Middle East, land and property, restitution, Iraq, post-war, ISIS, ISIL, law.

\section{$1 \quad$ Introduction}

Untangling the war-affected land and property rights problems in Iraq constitutes a significant and ongoing challenge. The history and magnitude of dislocations, conflicts, claims, counterclaims, cleansing, returns, damage and destruction constitutes a primary obstacle to the country's recovery and economic development; while at the same time serving as a significant source of animosity, violence, division, and instability. ${ }^{1}$ The legislative and institutional ability to adequately manage such a contentious problem as part of recovery is critical for the country. This article presents a critique of the intersection between some of the primary land and property rights problems in the country - as they emerge from both historical and contemporary processes - and the current legislative and institutional framework for land and property rights. Can the latter adequately manage the former? The aim of addressing this question is to contribute to the discussion of whether in-place frameworks or separate transitional justice frameworks are best suited for managing the recovery of war-affected land and property rights.

\footnotetext{
${ }^{1}$ H. Batatu, The Old Social Classes and the Revolutionary Movements of Iraq: A Study of Iraq's Old Landed and Commercial Classes and of its Communists, Ba'thists and Free Officers. (Princeton University Press, 2004). International Organization for Migration, Housing, Land and Property (HLP) Issues Facing Returnees in Retaken Areas of Iraq (Geneva: International Organization for Migration, 2016); International Organization for Migration, Community Stabilization Handbook: An Overview of Community Transition and Recovery Achievements in Iraq (Baghdad: International Organization for Migration Iraq Mission, 2016).
} 
Important in this examination is the historical trajectory of both the development of land and property rights problems in Iraq, and the legal and institutional progression that has both caused and sought to resolve various problems. These histories are important because in Iraq as in other countries with deep histories of conflict, land and property rights difficulties interlock over time, to form a chain of linkage between specific issues that emerged during certain periods, to then influence subsequent problems.

Subsequent to a description of the evolution of a set of land and property rights problems in Iraq in the context of changing laws and sources of conflicts, the article examines the current legal and institutional framework in the country and its ability to manage the land and property problems besetting the country in its current post-ISIS phase.

\section{Evolving Land and Property Rights: Law and Conflict}

\section{$2.1 \quad$ Legal History of Land Rights}

The ancient history of Iraq reveals forms of land rights associated with human settlement to be among the oldest in the world. The the structure of the land rights system has very deep historical roots, resulting in numerous land rights systems over the centuries. Some of these have evolved locally across tribes, sects, geographic locations, and religions; others have been imposed; and still others were imported. The present-day land tenure system is actually a set of embedded and overlapping systems which has many historical elements that can either be contradictory or cooperative, opposed or aligned, or apply only to certain groups and be discriminatory to others. At the same time, the legal culture in Iraq is deep, well established, and regarded with significant respect (particularly the Civil Code), albeit applied in different ways as state ideology has changed over time. ${ }^{2}$ The overall result however is a certain rigidity when attempting to make statutory laws relevant to a diverse and changing civil society. This is particularly the case in fluid war-affected circumstances, with the effect being to relegate the actual application of statutory laws to simply a matter of enforcement. Islamic law however, which plays a significant role in Iraqi land and property law, is known to be locally interpreted, allowing for multiple possible arrangements. ${ }^{3}$

Land in Iraq has traditionally been organized into categories derived from Sharia law that includes: mulk (privately owned), waqf or awaqf (charitable trust land), matrukah (publicly owned), mawat (unused land), and 'miri (land that is state owned but possessed by an individual). Most land is classified as 'miri and is regulated by state code. And while 'miri land is technically owned by the state, it can be possessed and used by individuals who retain what are known as tasarruf rights, which is the right to exploit, use and transfer the land. Over time the difference between absolute ownership rights and tasarruf rights narrowed to the extent that they

\footnotetext{
2 L. Al-Ossmi, \& V. Ahmed, 'Land Tenure Security According to Land Registration Systems in Iraq,' in Proceedings of the 12th International Post-Graduate Research Conference, MediaCity, UK, 10-12 June, 2015; D. Stigall, Refugees and Legal Reform in Iraq: The Iraqi Civil Code, International Standards for the Treatment of Displaced Persons, and the Art of Attainable Solutions (Amman: US Institute of Peace on Housing, Land and Property Rights in Iraq, 2009).

3 S. Sait, \& H. Lim, Land, Law and Islam: Property and Human Rights in the Developing Word (New York: UN Habitat and Zed Books, 2006).
} 
are now essentially insignificant in ordinary business matters ${ }^{4}$ Communal lands are those lands around a village that are commonly used by village members for nearly all purposes. ${ }^{5}$ And 'unit/ plot tenure' refers to a form of residence rights that are close to ownership rights. Leases are also a form of tenure in Iraq, with variations in terms and time periods. ${ }^{6}$ Table 1 summarizes the different forms of tenure, the practices under which they operate, and their legal sources.

The Ottoman period in Iraq (1534-1704 and 1831-1920) spanning some 400 years has significantly influenced the land tenure system. The Ottomans created a title deed system in which deeds were issued for 'miri land in the name of the state in order to counter the power of sheikhs who asserted control over income from 'miri lands. The Ottoman land administration system known as TAPU (title deed) provided for both deeds and a land register. The Ottoman Land Code of 1858 was one of the first government interventions that sought to regularize land rights by establishing categories of landholding and required surveys and registration of holdings. But by World War I only limited land registration had been achieved and land titles continued to be insecure, especially under tribal tenure systems through which the state retained ownership and tribes were allowed use rights. ${ }^{7}$

In the British mandate period (1920 - 1932) following the Ottomans, the landholding structure was designed (as it was during the Ottoman period) to reinforce political power through the provision of lands to individuals who were influential and supportive of the government inplace. The result was a great deal of land accumulation in few hands, and a peasantry that possessed very few rights in land. ${ }^{8}$ Beginning in the early 1930s the Iraqi state pursued a number of land reform interventions in an attempt to deal with the acute land distribution problems. ${ }^{9}$ This included resettlement and reclamation efforts in the 1940s, and settlement on state land for certain individuals, together with programs of development in the 1950s. Following the socialist revolution in 1958 the government claimed all large landholdings, registered them as 'miri land and redistributed them to cooperative societies and individuals in smaller parcels. ${ }^{10}$ The redistribution was facilitated by the 1958 Iraqi Agrarian Reform Law which specifically sought to pro-

4 M. Wiss \& M. Anderson The Unique Forms and Rights of Iraqi Real Property Law: A Primer for Those Interested in Transacting Business in Iraq (International Bar Association, 2009) (Available at: https://www.ibanet.org/Article/NewDetail.aspx? ArticleUid=E2F9FB38-C584-4854-972C-95378836F941)(Accessed March 18, 2018).

5 F. Ziadeh 'Land law and economic development in Arab countries', The American Journal of Comparative Law 33, no 1 (1985): 93-106.

6 M. Wiss \& M. Anderson The Unique Forms and Rights of Iraqi Real Property Law: A Primer for Those Interested in Transacting Business in Iraq (International Bar Association, 2009) (Available at: https://www.ibanet.org/Article/ NewDetail.aspx? ArticleUid=E2F9FB38-C584-4854-972C-95378836F941)(Accessed March 18, 2018)..

7 H. Metz, Iraq: A Country Study. (Washington: GPO for the Library of Congress, 1988).

8 Research Triangle Institute (RTI), Land Registration and Property Rights in Iraq (Research Triangle Park, NC, USA, Research Triangle Institute International, 2005); F. Baali, Land Tenure and Rural Social Organization: A Study in Southern Iraq. PhD. Dissertation, Department of Sociology, Louisiana State University, Baton Rouge, 1960.

9 H. Metz, Iraq: A Country Study. (Washington: GPO for the Library of Congress, 1988).

10 M. Wiss \& M. Anderson The Unique Forms and Rights of Iraqi Real Property Law: A Primer for Those Interested in Transacting Business in Iraq (International Bar Association, 2009) (Available at: https://www.ibanet.org/Article/NewDetail.aspx? ArticleUid=E2F9FB38-C584-4854-972C-95378836F941)(Accessed March 18, 2018). 
vide a remedy for the large inequities in landholdings. This included the inequity of opportunity for acquiring land during Ottoman rule between 1514 and 1918 and which continued under British rule. This inequity resulted in approximately 80 percent of the land being owned by less than 2 percent of the population. The 1958 law was a landmark intervention in the history of Iraq and promised change from land-based feudalism toward private holdings. The results were chaotic in rural areas however because the government at the time lacked the capacity for effective implementation. ${ }^{11}$

During the Ba'athist period (1963 - 2003) the change to a socialist ideology led to the implementation of large-scale land reform in the rural tribal areas in which limitations on landholding size were enacted, and collective ownership and agricultural production pursued. Two land reform interventions in the form of a 1970 law and a 1975 law, sought to break up large landholdings. And in 1974, the Real Estate Registration Law replaced the TAPU system, establishing Real Estate Registration Departments and creating an improved title issuing service. Despite the intention of these laws, other ongoing government interventions resulted in the government gaining possession of large areas of agriculturally productive land. In the 1980s intervention in the land sector was incoherent. First the government turned to land collectivization and by 1981 had established 28 collective state farms that cultivated approximately 180,000 ha. In 1983 the government then produced a law encouraging local and foreign Arab investments in leasing larger plots of land from the government. And by 1987 the government produced plans to re-privatize agricultural land. ${ }^{12}$

In the later Ba'athist period supporters of the regime received government land, while at the same time those of Persian descent and Kurds had land expropriated even though they held title. ${ }^{13}$ In this period both rights to land and tenure (in)security were used to punish and reward citizens. At the same time processes for transacting property and registration and applications for improvements were quite lengthy but regarded as fairly effective. Such that by 2005 approximately 96 percent of land owners indicated that their property was registered, however fewer than 3 percent of owners had mortgages. ${ }^{14}$ With the deterioration of authority and institutions following the Second Gulf War, fraudulent titles then became increasingly common. ${ }^{15}$

Thus the current legal framework for land rights in Iraq draws on multiple sources and ways of operating that have evolved over considerable time. Islamic law and Ottoman era law continue to influence the legal framework for land in Iraq, as does Egyptian and French law. In the 20th century Iraq blended in elements of the civil law tradition and produced its own Civil

\footnotetext{
11 K. Al-Yasiri, The Agrarian Reform Law of 1958: A Catalyst for Economic and Social Development in Iraq, PhD. Dissertation, Department of Agricultural Economics, Iowa State University, 1965).

12 H. Metz, Iraq: A Country Study. (Washington: GPO for the Library of Congress, 1988).

13 Research Triangle Institute (RTI), Land Registration and Property Rights in Iraq (Research Triangle Park, NC, USA, Research Triangle Institute International, 2005)

14 ibid.

15 ibid.
} 
Code. ${ }^{16}$ Iraqi law is thus a blend of Western and Middle Eastern legal traditions. Presently Iraq embraces the civil law system as do other countries in the Middle East.

Legal pluralism with regard to land rights in Iraq has created both problems and opportunities. Problems, in that certain aspects of older land rights systems, coming from both from within and outside the country over time, still influence how land rights operate today, providing for a certain degree of confusion. This is the case for common law as well as legislated law. In addition, laws from different eras are aligned with the governing ideology of their respective time periods and do not always reflect the current legal environment, problems, or aspirations of the country. Opportunities, in that such a history provides a rich source of legal land and property concepts, techniques, institutional material and experience that will be needed in order for land and property rights to robustly contribute to Iraq's recovery and economic development.

\section{$2.2 \quad$ Sources of Land Conflicts}

\subsubsection{Historical}

Of significant influence on the history of land rights in the country are the many waves of forced dislocations that have occurred over the centuries, but particularly in recent decades. These largescale dislocations, occurring over multiple ethnicities, sects, locations and time periods, means that claims from previous dislocations clash with those from more recent dislocations and are overlain on often competing ethnic territorial claims. Thus historical dislocations and land conflicts continue to be relevant today. Historical land-related conflict in Iraq stems primarily from the long succession of invasions and conflicts between the different sects, ethnicities and those in power; and the resulting dislocations of populations from their lands and properties over time. Surges of resettlement and attempts at reclaiming lands (including by descendants generations later) is an ongoing and primary source of land conflict in the country. Short and long-term displacements in the past 50 years have resulted from dispossession by the Ba'athist regime, terrorism, foreign and domestic military operations, sectarian violence, and economic and legal processes. ${ }^{17}$

Even under Ottoman rule, the area that is today Iraq comprised a battle zone between rival regional empires and tribal alliances. ${ }^{18}$ Uprisings and reactions against governments, sects, and ethnicities continued subsequent to Ottoman rule when Iraq briefly became a kingdom, then a republic in 1958. The Ba'athist era was known for large-scale population displacement and replacement based on ethnicity, particularly in the north with regard to the Kurdish, Turkoman and Assyrian populations. Official displacement of Iraqis of ethnic Persian descent from their lands began in 1979 and lasted into the 1980s, with the property then sold on to Ba'athist supporters, and then often resold at a profit. Similar official dislocations took place among the Kurds and Turkmen in the vicinity of Kirkuk. ${ }^{19}$ Ba'athist-era land expropriations by government were ex-

16 D. Stigall, 'A closer look at Iraqi property and tort law', Louisiana Law Review 68, no. 3 (2008): $765-822$.

17 D. Isser \& P. van der Auweraert, Land, Property and the Challenge of Return for Iraq's Displaced (Washington DC, US Institute of Peace Special Report 221, 2009).

18 B. Milton-Edwards, 'Iraq, Past Present and Future: A Thoroughly Modern Mandate?' History \& Policy, May 8, 2003.

19 Research Triangle Institute (RTI), Land Registration and Property Rights in Iraq (Research Triangle Park, NC, USA, Research Triangle Institute International, 2005) 
tensive and continue to be a source of numerous land disputes and ethnic animosity. The expropriations primarily took place in order to solidify control over valuable oil and arable lands and punish groups opposed to the government. Based in Ba'athist laws, the expropriations involved hundreds of thousands of people, and were followed by an Arabization policy to fill the vacated land with Arab settlers. ${ }^{20}$ In addition, the Algiers Agreement of 1975 led to the forced dislocation of ethnic minorities to collective townships where they were not allowed to register their assigned parcels in their own names. ${ }^{21}$ Following the Iran-Iraq war in the 1980 s, insurrections continued to plague the country involving demoralized soldiers, the Kurdish population, and the drainage of the marshlands and forcible relocation of the Marsh Arabs. The 2003 invasion by Coalition Forces added to the dislocation - relocation - conflict process, as has the conflict with ISIS, and the recent takings and re-takings of lands involving the Iraqi government and Kurdish forces. ${ }^{22}$ And with each new conflict and dislocation, descendants of those previously dislocated from the area use the opportunity to attempt to reclaim their ancestors' lands. ${ }^{23}$

The agrarian reform efforts of the 1970s also generated land and property conflicts between those who lost land and those who currently own it. A 1970 law reduced the maximum size of landholdings to between 10 and 150 ha of irrigated land and between 250-500 ha of nonirrigated land. Holdings above these maximums were often expropriated. In 1975 an additional reform law sought to break up the large estates of Kurdish and tribal landholders, resulting in expropriations and then disputes once the Ba'athist regime ended. Additional expropriations worsened the Ba'athist government's land rights, management and conflict problems, and resulted in the government coming to hold a large percentage of arable land which subsequent to the regime's end became intensely contested.

Broader processes also contributed to land tensions and conflicts. The $1991 \mathrm{Gulf}$ War damaged the irrigation and transportation infrastructure, to the degree that agricultural productivity declined significantly. Salinization then expanded across much of the irrigated area in the country's central and southern regions, with these then becoming much less usable. Rural labor shortages after the 1991 war resulted in less area under agriculture - with much of the shortage due to the departure of foreign guest workers. ${ }^{24}$ International sanctions added to these difficulties. In an attempt to manage land use and agricultural productivity after the war, the government raised the official price of major field crops and expanded the area to be put under cereal crop production in the north of the country. The government then confiscated land from farmers who did not meet production quotas. ${ }^{25}$

${ }^{20}$ H. Mufti, Claims in conflict: reversing ethnic cleansing in northern Iraq (Human Rights Watch, 2004).

21 Protection Cluster Iraq, Emergency Response to Housing Land and Property Issues in Iraq (Geneva: Protection Cluster Iraq Briefing Note, December, 2016).

22 S. Barbarani, ‘A look into Iraq's disputed Kirkuk before the referendum.’ Aljazeera 24 September, 2017.

23 Author interviews with International Organization for Migration Reparations Programme-Iraq officials, and Iraqi and Kurdistan government officials, July 2017.

24 R. Schnepf, Iraq's Agriculture: Background and Status (Washington DC: CRS Report for Congress, The Library of Congress, 2003).

25 ibid. 


\subsubsection{Contemporary}

Displacement of land and property during and subsequent to Iraq's more recent conflicts have affected millions, with the recent number of displaced due to the ISIS war approximating 3.3 million. ${ }^{26}$ As this population now attempts to return, they are encountering those who were displaced in the Ba'athist era seeking to return to the same lands, with the inevitable conflicts difficult to resolve peaceably given the absence of specific laws and institutions to do this in recently ISIS retaken areas. ${ }^{27}$

Land tenure security is significantly low in many areas of the country due to the recent conflict with ISIS, and the associated dislocations, secondary occupation, and temporary residence. The result is a situation of competing claims, use of militias to secure and enforce claim assertions, and ethnic and sectarian claims to large areas merging with individual and family claims - with no widely agreed upon ways to resolve these. In addition, the conflict-related loss of property documents and the surge in falsified documents, together with institutional, authority and enforcement deficits, further compromise tenure security for many. ${ }^{28}$ Women face particular difficulty in re-claiming land and property subsequent to forced dislocation in the country because they continue to hold subservient rights. This becomes particularly difficult when the property in question is in the name of a missing or deceased male family member, or when there is no documentary evidence of the relationship in the woman's possession, or documents attesting to the male kin's death or disappearance do not exist, resulting in an inability to claim the relevant property. ${ }^{29}$

Many current land-related conflicts in the country can be categorized into three broad sources: 1) conflicts associated with the three contemporary periods of large-scale dislocation (Ba'athist, coalition forces, ISIS) complicated by historical claims; 2) the overlap and confusion between land rights for individuals and rights claimed by groups involving ethnic and sectarian territoriality; and 3) a weak state presence and low capacity in large areas of the country and the filling of this vacuum with tribal, Islamic, militia, extremist and hybrid approaches to managing land rights.

26 UN High Commisioner for Refugees, Iraq Displacement, 2017 (Available at: http://reporting.unhcr.org/node/ 2547\#_ga=2.74002066.1847831292.1505761546-907952754.1492093717) (Accessed 10 December, 2017); International Organization for Migration, Integrated Location Assessment: Governorate Profiles (Baghdad: International Organization for Migration, Iraq Mission, 2017).

27 Author interviews with UN and NGO researchers in norther Iraq, and an Iraqi tribal leader in October 2016, and November 2017.

28 International Organization for Migration, Housing, Land and Property (HLP) Issues Facing Returnees in Retaken Areas of Iraq (Geneva: International Organization for Migration, 2016); International Organization for Migration, Community Stabilization Handbook: An Overview of Community Transition and Recovery Achievements in Iraq (Baghdad: International Organization for Migration, Iraq Mission, 2016).

29 Protection Cluster Iraq, Strategy of the Iraq Housing Land and Property Rights (HLP) Sub-Cluster (Geneva: Global Protection Cluster, 2016); Food and Agricultural Organization, FAO Gender and Land Rights Database, FAO, Rome. (Available at: http://www.fao.org/gender-landrights-database/data-map/statistics/en/?sta_id=1162 2017) (accessed March 18, 2018). 
The first source was reviewed above, and essentially involves returnees finding others on their lands, or that demographic change along sect, ethnic, or religious lines has occurred in certain areas. Of secondary importance are returnees who find their land and property damaged or destroyed and then must seek other lands and properties from which to pursue livelihoods, which in turn causes conflicts with the returning owners of those properties. ${ }^{30}$

The second type of land conflict is that which is caught up in the assertions and defence of ethnic or tribal territoriality, played out at the level of the household. While usually sectarian, this is most acute between areas claimed by both the Kurdish population and the federal government. While the military efforts by both sides are important in this regard, equally important are the neighborhood-level land and property interactions by individual members of various ethnic groups that encourage dislocation, or promote or prohibit return to certain areas by specific ethnic groups or tribal members. ${ }^{31}$ The October 2017 takeover of Kirkuk by Iraqi forces together with the the Shia Popular Mobilization Units (PMU) resulted in approximately 100,000 primarily Kurdish civilians fleeing the city, with their homes and properties looted and destroyed by other civilians. At the same time the city itself resides on disputed land claimed by Arabs and Turkomans in addition to the Kurds. ${ }^{32}$ Many land conflicts in the country constitute an embedding of individual claims and conflicts within opposed territorial claims pursued by tribes, sects and ethnicities, and often there is no clear distinction between the individual and group conflicts.

The third type of land and property conflict is more tied to the relatively weak presence of state institutions in insecure and more peripheral areas, leaving these populations to engage in a variety of customary, tribal, religious and state (or hybridized) approaches to land and property rights, often backed up by local militia enforcement. ${ }^{33}$

\section{The Current Legal and Institutional Framework}

Given the problematic historical-to-contemporary land conflicts and tenure insecurity in the country, what do different components of the current legal and institutional framework provide in terms of either, 1) a capacity to resolve these in the volume and timeliness required and offer protections from further loss of land rights, or 2) a degradation of the overall situation by facilitating expropriations, confusion, neglect and conflict. This section examines and critiques the primary components of the Iraqi legal and institutional framework for land and property rights currently in place, with regard to its ability to mitigate or exacerbate conflict and insecurity over land.

\footnotetext{
${ }^{30}$ Household survey of 110 internally displaced persons (IDPs) conducted by the NGO Social Inquiry for the Author's research team, in July 2017.

31 Author interviews with Kurdish and Iraqi government officials, October, 2016.

32 M. Chmaytelli, Kurdish officials say thousands flee Kirkuk since Iraqi army takeover, Reuters, October 19, 2017.

33 R. Guiu, 'Early recovery programming as a means of combating civilian recruitment and militarization in Iraq,' Social Inquiry 2018, (Available at: https://social-inquiry.org/ early-recovery-programming-as-a-means-of-combating-civilian-recruitment-and-militarization-in-iraq-25e03bf212e6 2017) (accessed March 18, 2018).
} 


\subsection{The Legal Domain}

The Iraqi Civil Code embodies the history of Iraqi legal development and contains the primary laws dealing with land and property. Thus it is the primary source of law regarding restitution, compensation and protection associated with forced displacement and returns. ${ }^{34}$ Stigall ${ }^{35}$ describes the land and property rights aspects of the Civil Code in significant depth. There is a debate however as to whether the Civil Code and other relevant laws are up to the challenge of resolving the land and property problems in the country, in the magnitude and complexity that they exist and with the speed and cost needed to effectively address them. Stigall ${ }^{36}$ along with some Iraqi lawmakers spoken to argue that elements of the civil code are well up to the task of legally engaging the needed conflict resolution and restitution processes. Certain international agencies with long experience working on land and property problems in war-affected scenarios however, argue that the need for a rapid, large-scale restitution of land and property is best handled by additional laws and a separate commission more aligned with an internationally sponsored transitional justice process. In a certain sense both are correct, in that while the Civil Code and other laws do appear to possess the means, depth and legitimacy to manage the nature of the land rights problems currently besetting the country; the relevant laws and elements of the Civil Code able to do this are variously uncoordinated, unorganized, at times contradictory, difficult to access for many Iraqis, difficult to implement, unenforceable and open to multiple interpretations, manipulation and disregard.

Among the more useful elements of the Civil Code, the complete protection of private property is provided for. And pertinent to the issue of displacement and restitution, the Civil Code stipulates that one does not lose ownership of land and property through non-use. As well any possession of land and property obtained through coercion or ambiguity is countered, and applies to those who have lost land to secondary occupation through violence or deception. ${ }^{37}$ Thus there is no legal recognition of a militia member who occupies land by force. As well articles 192 to 201 of the Civil Code provide remedies for usurpation and misappropriation of land and property. 38

Other elements in the Civil Code however are more problematic, such as how tasarruf rights are handled. A person in possession of 'miri land is entitled to tasarruf rights, which can be used as security for a loan. However if a tasarruf holder leaves land unused for three years without cause, rights to the land are forfeited. This is important because tasarruf rights holders occupy approximately 70 percent of all land in Iraq. At the same time however the Iraqi constitu-

\footnotetext{
34 D. Stigall, Refugees and Legal Reform in Iraq: The Iraqi Civil Code, International Standards for the Treatment of Displaced Persons, and the Art of Attainable Solutions (Amman: US Institute of Peace on Housing, Land and Property Rights in Iraq, 2009).

35 D. Stigall, 'From Baton Rouge to Baghdad: a comparative overview of the Iraqi Civil Code,' Louisiana Law Review 65, no. 1 (2004): 130-156; D. Stigall, 'A closer look at Iraqi property and tort law,' Louisiana Law Review 68, no. 3 (2008): 765-822; ibid.

36 ibid.

37 ibid.

38 ibid.
} 
tion attempts to strike a balance between needs of the individual and those of the state and protects tasarruf holders from expropriation without compensation. ${ }^{39}$

Other legal devices in Iraq play a role in land and property conflict resolution. Of relevance to Iraq's large internally displaced population is Law No. 20 of 2009, 'Compensating the Victims of Military Operations, Military Mistakes and Terrorist Actions.' This law seeks to provide compensation for damage to land and property (along with loss due to those killed in battle, disability and injuries, and problems affecting employment and study) due to military operations. However, the law does not cover compensation for property that has been confiscated, sold under duress, or illegally occupied. Compensation for property loss under Law 20 is awarded on a case by case basis, instead of a set of mass claims procedures more relevant to the many thousands of disputes. ${ }^{40}$ The case by case treatment of claims greatly lengthens the process of awarding compensation given the large numbers of claims (approximately 65,000 between 2011 and 2016). ${ }^{41}$ Parliament approved an amendment to Law 20 in 2015 resulting in an expansion of the scope of the law with regard to persons covered, but created additional delays. Law 20 has been criticized for its bureaucratic and time-consuming functioning, weak institutional framework, and arduous evidentiary requirements, necessitating the acquisition of numerous government documents from different offices. ${ }^{42}$ This functioning is contrary to international best practice for war-affected land and property rights restitution processes, which emphasize simple, streamlined functioning resulting in timely decisions and remedies for whole categories of claims, and a lower than usual standard of evidence. ${ }^{43}$ An additional problem is that the reparations process attached to Law 20 is unconnected to the reality of displacement with regard to: claims submission, evidence gathering, distribution of compensation, and ongoing insecurity. ${ }^{44}$ And while many claimants have received positive decisions for their cases under Law 20, no money or alternative land was actually provided. One concern of some lawmakers is that this law is difficult to pursue for individuals without the assistance of a legal expert. ${ }^{45}$

An additional well intended legal device is Article 140 of the Iraqi Constitution of 2005, which sought to resolve long-standing issues involving disputed lands and territories that primarily affect minority groups. A political impasse regarding the implementation of Article 140 how-

39 M. Wiss \& M. Anderson The Unique Forms and Rights of Iraqi Real Property Law: A Primer for Those Interested in Transacting Business in Iraq (International Bar Association, 2009) (Available at: https://www.ibanet.org/Article/NewDetail.aspx? ArticleUid=E2F9FB38-C584-4854-972C-95378836F941)(Accessed March 18, 2018).

40 Author interviews with Iraqi lawmakers, October, 2016.

41 C. Sandoval \& M. Puttick, Reparations for the Victims of Conflict in Iraq (London: Ceasefire Center for Civilian Rights, November, 2017).

42 ibid.

43 H. Holtzmann \& E. Kristjansdottir, International Mass Claims Processes: Legal and Practical Perspectives Remedies (Oxford: Oxford University Press, 2007); J. van Haersolte-van Hof, Innovations to Speed Mass Claims: New Standards of Proof," in Permanent Court of Arbitration (ed.), Redressing Injustices Through Mass Claims Processes, pp. 13-24. (Oxford: Oxford University Press. 2006).

44 C. Sandoval \& M. Puttick, Reparations for the Victims of Conflict in Iraq (London: Ceasefire Center for Civilian Rights, November, 2017).

45 Author interviews with Iraqi lawmakers, October, 2016. 
ever has instead frozen the land allocation process in areas to which it was to have been applied. ${ }^{46}$

Some Iraqi laws act to inhibit the ability of the Civil Code to provide legal redress for dispossession, and have instead been used to expropriate land and property for a variety of reasons, including those based on ethnicity or sect. This, combined with the relative weakness of statutory law and state presence in the more peripheral areas, creates a trust deficit for civil society. Nine current laws apart from the Civil Code that seek to manage land and property rights can be regarded as problematic in the context of their use in expropriations. These include:

The Real Estate Registration Law of 1974 can allow the transfer of land and property in some cases of coercion. ${ }^{47}$

The Lease Law No. 87 of 1979 which supersedes the Civil Code, provides for eviction for nonpayment of rent after a prescribed time period (Article 17(1)). And Article 17(7) of the law stipulates that land and property that is uninhabited for more than 45 days can result in eviction. ${ }^{48}$

Resolution No. 333 Promulgates Law No. 42 of 1987. This legislation is concerned with the reorganization of agrarian ownership under reclamation projects. The law is focused on the reorganization of land ownership for lands subject to agricultural projects. However it also provides remedies for compensation to land owners for expropriation. 49

Iraqi Company for Contracts for Land Reclamation Law No. 116 of 1981 . The law establishes the Iraqi 'Company for Contracts of Land Reclamation' under the Council of Ministers. The Company implements reclamation projects and acts as a contractor for reclamation projects. The Company can sell and lease reclaimed lands and the properties of the company are considered 'state domains'.50

The Agrarian Reform Law No. 117 of 1970. Comprising five chapters and 52 articles, this extensive law covers a variety of agricultural land ownership issues, including the maximum size limit of lands owned privately without authorization. The Agrarian Reform Authority can requisition lands above the stated limit and stipulate the forms of compensation that the owner of the requisitioned excess land is due. The Authority distributes agrarian reform lands to those it deems in need, both individually and collectively. 51

\footnotetext{
46 Protection Cluster Iraq, 'Emergency response to housing land and property issues in Iraq' (Protection Cluster Iraq Briefing Note, December, Geneva, 2016).

47 D. Stigall, Refugees and Legal Reform in Iraq: The Iraqi Civil Code, International Standards for the Treatment of Displaced Persons, and the Art of Attainable Solutions (Amman: US Institute of Peace on Housing, Land and Property Rights in Iraq, 2009).

48 ibid.

49 Government of Iraq, Resolution No. 333 Promulgates Law No. 42 of 1987 (Baghdad: Government of Iraq, 1987).

50 Government of Iraq, Iraqi Company for Contracts for Land Reclamation Law No. 116 of 1981 (Baghdad: Government of Iraq, 1981).

51 Government of Iraq, Agrarian Reform Law No. 117 of 1970 (Baghdad: Government of Iraq, 1970).
} 
Law of 2013 Confirming Ownership of the Agricultural Lands and Orchards Excluded from the Adjustment Acts. This law operates within the Municipality of Baghdad and deals with orchards and agricultural lands that were excluded from previous settlement acts or are otherwise of unresolved ownership status. The Law focuses on urban development that takes place on agricultural and orchard lands that have become unsuitable for agriculture due to urban development. The Law establishes 'Land and Expropriation Committees,' which were initially promulgated by the Agrarian Reform Law of 1970. The Committees determine the rights over such lands and remove the definition of 'agricultural land' if in the old registers of the city they were not officially designated as 'agricultural land'.52

Law No. 2 of 1983 on Pasture. This law intends to manage pasture lands by planning grazing according to scientific approaches, and engaging in the protection of natural vegetation and water resources, and the organization of their use. The Law covers state-owned lands allocated for pasture. The Law states that the Ministry of Agriculture and Agrarian Reform is to regulate and organize livestock movements according to seasons and regions. The law prohibits the drilling of artesian wells and cutting plants in pasturelands. ${ }^{53}$

Resolution No. 150 of 1997 Concerning the Sale of Plots of Land for Housing Owned by the State to Farmers. The Resolution stipulates that state owned land not burdened by 'disposal rights' shall be sold to farmers, with pre-existing agricultural contracts revoked and pre-existing rights extinguished. The Resolution provides limits of the allocation to farmers - not more than $1,000 \mathrm{~m} 2$ with no house and $2000 \mathrm{~m} 2$ for a plot with a house. ${ }^{54}$

Resolution Concerning Agricultural Land. Unofficial title, No. 211 of 1991. This resolution stipulates that agricultural lands owned by the state which are cultivated by persons themselves or through others, shall be considered as property of the state with no compensation due; and shall be registered in the name of the Ministry of Finance as 'pure' property. The Ministry of Agriculture shall dispose of such lands in accordance with laws and regulations in force. 55

While the above laws can be applied in the context of an unjust expropriation, at the same time two laws seek to manage aspects of expropriated land and property for those able to access and use them.

Resolution Relative to Corporeal Compensation for Appropriated Real Estates and Amortization of the Right of Disposal of Vacant Agricultural Reform Lands No. 90 of 1996. This law provides for compensation for the alienation of agricultural land with alternative land as a first priority

\footnotetext{
52 Government of Iraq, Law of 2013, Confirming Ownership of the Agricultural Lands and Orchards Excluded from the Adjustment Acts (Baghdad: Government of Iraq, 2013).

53 Government of Iraq, Law No. 2 of 1983 on Pasture (Baghdad: Government of Iraq, 1983).

54 Government of Iraq, Resolution No 150 of 12 October 1997 Concerning the Sale of Plots of Land for Housing Owned by the State to Farmers (Baghdad: Government of Iraq, 1997).

55 Government of Iraq, Law No. 211 Resolution Concerning Agricultural Land. Unofficial Title (Baghdad: Government of Iraq, 1991).
} 
and cash compensation as a secondary priority. The law prohibits compensation in-kind or cash for certain types of land. 56

Resolution to Prevent Alienating of Estate Property of Iraqi Citizens who left Iraq, No. 21 of 1996. The resolution stipulates that the transfer of real estate owned by Iraqi citizens who left the country is to be prevented in all cases. ${ }^{57}$

In addition to the expropriation-related uses of certain laws, three problematic legal contexts exist. First, because laws and regulations not explicitly amended or superseded continue to be in force, certain older laws are in conflict with subsequent laws due to this omission. Second, the set of laws currently in place reflect different legal ideologies and purposes, adding confusion (and the resulting tenure insecurity) as to what laws apply to whom, where and how. Third, there are a set of laws that outlaw certain day to day activities of specific livelihoods that are beyond the capacity of the state to enforce, and open up opportunities for corrupt application — such as the pasture law. 58

In a significant opportunity, Iraqi lawmakers acknowledge the very important role of tribal law as an alternative in managing land and property issues, including dispute resolution. They see tribal law (and those that operate them) as partners to a certain degree in the administration of land and property, and they underscore the relevance of efforts to bring tribal law and statutory law together in mutually supportive ways. ${ }^{59}$ Iraq has a significant history of fusing different forms of law, a clear advantage in the present circumstances where the state can have limited reach in certain areas. Hamoudi et al discuss at length the different aspects of interaction between tribal and statutory law in Iraq, and the potential this interaction provides. ${ }^{60} \mathrm{Such}$ a phenomenon is not particular to Iraq however, with various forms of 'legal pluralism' being widely observed and operational. ${ }^{61}$ Exploring the different alternative dispute resolution approaches that tribes and lineages already use and that can be connected to statutory law in mutually supportive ways, would be worthwhile, but has not yet occurred. This would be particularly important given that tribal dispute resolution laws and institutions will be present in areas of return for IDPs well before functioning, efficient state institutions seen as legitimate by civil society are able to be-

\footnotetext{
56 Government of Iraq, Law No 90 Resolution Relative to Corporeal Compensation for Appropriated Real Estates and Amortization of the Right of Disposal of Vacant Agricultural Reform Lands No 90 of 1996 (Baghdad: Government of Iraq, 1996).

57 Government of Iraq, Law No 21 Resolution to Prevent Alienating of Estate Property of Iraqi Citizens Who Left Iraq, No. 21 of 1996 (Baghdad: Government of Iraq, 1996).

58 Government of Iraq, Law No. 2 of 1983 on Pasture (Baghdad: Government of Iraq, 1983).

59 Author interview with Iraqi lawmakers and tribal leaders, October 2016, November 2017.

60 H.A. Hamoudi, W.H. Al-Sharaa, A. Al-Dahhan, 'The resolution of disputes in state and tribal law in the south of Iraq: Toward a cooperative model of pluralism, in, M. Helfand (ed.), Negotiating State and Non-State Law, pp. 215260 (Cambridge University Press, 2015)

61 H.A. Hamoudi, 'Decolonizing the centrist mind: legal pluralism and the rule of law, in, D. Marshall (ed.), The International Rule of Law Movement: A Crisis of Legitimacy and the Way Forward. pp. 135-165, (Harvard University Press, 2014); J. Griffiths 'What is legal pluralism?', Journal of Legal Pluralism 24 (1986): 1-55.
} 
come re-established. ${ }^{62}$ Thus tribal law would not add an additional layer of law where state law does not yet exist.

\subsection{The Institutional Domain}

While current statutory institutions in Iraq for land and property are designed to deal with a variety of issues in stable social-political settings, none have the mandate or capacity to manage the very large numbers of claims and conflicts currently emerging. The current institutional structure pertaining to land in Iraq broadly comprises six ministries and local boards. ${ }^{63}$ In addition there are two special institutional-legal processes that are designed to deal with specific periods of dislocation and restitution. This sub-section very briefly describes these and then offers an overall critique.

\subsubsection{Line Agency Institutions}

The Ministry of Agriculture's mandate since the Agrarian Reform Law No. 30 of 1958, has been to pursue the best investment in agricultural lands and stability in agricultural relations for the country. The Ministry supervises the implementation of legislation for agriculture regarding farm ownership, transaction of farmland and patterns of agricultural land possession rights.

The Ministry of Justice was given renewed authority under the Coalition Provisional Authority (CPA). The resulting law (No. 18) of 2005 included in the Ministry's mandate the supervision of the real estate registration departments.

The Ministry of Housing and Construction is the national housing authority and works with local government units at the governorate level to establish housing programs. A National Housing Office represents the Ministry in the private sector. The Ministry is responsible for implementing national housing plans.

The Ministry of Municipalities and Public Works is responsible for making national policy relating to municipal matters, including the implementation of facilities for cities. Within this Ministry the General Directorate of Urban Planning deals with urban planning at the local level.

The Physical Planning Commission is a local level division of the General Directorate of Urban Planning and is the regulatory board for urban land use working through the local Municipality Offices. The Physical Planning Commission is tasked with monitoring and supervising the implementation of local land use regulations and development.

The Municipalities Offices are the local government department of the Ministry of Municipalities and Public Works and deals with the implementation of development within cities and surrounding villages as designated by the cities' master plan.

62 Author interview with the individuals operating the UN's community policing program, November, 2017.

63 L. Al-Ossmi, \& V. Ahmed, 'Land Tenure Security According to Land Registration Systems in Iraq,' in Proceedings of the 12th International Post-Graduate Research Conference, MediaCity, UK, 10-12 June, 2015; Iraqi Ministry of Planning, 'Iraq Ministry of Planning' (Available at: http://www.mop.gov.iq/ mop/index.jsp?\&lng.) (accessed December 13, 2016). 
Despite the range of institutions involved in land administration, three complications significantly limit their effectiveness. First, while the statutory land administration system legally covers the entire country, the system is centralized and administration and enforcement in more peripheral areas is difficult and in many places absent. Thus while recent research among IDPs indicates that many Iraqis do value statutory documents and the state institution system, they do so more for proving tenure status in the future, and less so for securing rights in the present. 64 Second, the institutional logistics of applying the law quickly and fairly for very large numbers of claims, counter-claims and conflicts emerging from war-affected scenarios, easily overwhelms the capacity of institutions designed for stable socio-political settings. Third is the diminished capacity of the institutions themselves after being compromised by decades of war, distrust and suspicion, particularly in the northern Sunni areas. ${ }^{65}$

\subsection{2 'Special Processes' in Iraq}

There are two institutional-legal processes specifically designed for war-affected land and property conflict resolution and restitution in Iraq, each designed for a specific period of dislocation. The first was derived subsequent to the fall of the Saddam Hussein regime in 2003. The Coalition Provisional Authority initially established the Iraqi Property Reconciliation Facility as a dispute resolution mechanism, and this was then succeeded by the Iraq Property Claims Commission (IPCC) in 2004 that sought to attend to the Ba'athist era dislocations. The specific purpose of the IPCC was to resolve disputes that arose from the Arabization policy of the Ba'athist regime between 1963 and 2003. The IPCC was then replaced by the Commission for the Resolution of Real Property Disputes (CRRPD). The effectiveness of the IPCC and the CRRPD has been uneven however due to a lack of awareness of its existence and how it operates among the affected population, the challenge of handling the large number of claims in a timely way, an overly complicated and bureaucratic functioning, and the lack of enforcement for claims that have been decided. ${ }^{66}$ In addition, the remedies are widely viewed as insufficient, offered in a 'take it or leave it' fashion, and the process for obtaining remedies is overly bureaucratic, cumbersome and time-consuming; with the result being that the effectiveness of remedies is quite diminished. The CRRPD is a large slow moving endeavour involving a set of multiple institutions and many procedures to work through in order to reclaim lands and properties. There are strong preferences within civil society that it be made much quicker, more efficient, and with far fewer steps in order to effectively serve the intended population. In addition there is a desire that the CRRPD expand the types of remedies to include more than simply return to one's lands or minimal compensation. ${ }^{67}$

64 Household survey of 110 IDPs conducted by the NGO Social Inquiry for the Author's research team, in July 2017.

65 Author interviews with Iraqi lawmakers, and UN and NGO personnel working in northern Iraq, October 2016; November 2017.

66 Protection Cluster Iraq, Emergency Response to Housing Land and Property Issues in Iraq (Geneva: Protection Cluster Iraq Briefing Note, December, 2016); Digitally Designed HLP, 'Survey of digital technology and social media use among Iraqi IDPs,' Digitally Designed HLP. Accessed March 18, 2018. (Available at: http://digitalhlp.com) accessed March 18, 2018).

67 Author interviews with Iraqi NGOs, IDPs, and UN personnel working in Iraq, October 2016, November, 2017. 
The second process is intended to manage the restitution and remedies for the dislocations resulting from the conflict and ensuing problems that emerged between 2003 and the onset of the ISIS incursion in 2014. In this case Decree 262 of 2008 and Order 101 of 2008 were issued to facilitate IDP return and claims, along with a reiteration of the Anti-Terrorism Law that secondary occupation is unlawful. ${ }^{68}$ Decree 262 however covers only minimal forms of compensation for the displaced - involving those remaining in displacement returning to places of origin and rent assistance for Baghdad under certain circumstances. ${ }^{69}$ The decree does not provide a land and property restitution process, or assistance for secondary occupation, conflicts, or damaged or destroyed properties. Order 101 of 2008 deals with secondary occupation by way of a warning that such occupation is illegal, and secondary occupants have one month as of 1 August 2008 to resolve their situation. The Order provides for assistance by the Ministry of Justice's Reconciliation Committee for assessing legal documents as to ownership and occupation. ${ }^{70}$ Enforcement of this order took place with a large-scale eviction and property restitution effort, and the Iraqi army was tasked with evicting squatters, facilitating return, and restitution of property. ${ }^{71}$

There is however ongoing confusion as to how these two laws are to be implemented, and which Iraqi institutions are responsible for this. ${ }^{72}$ But as well the laws are out of reach for most IDPs, in terms of accessibility and the understanding needed to use them. ${ }^{73}$ There as been an absence of the state and effective institutions to implement the laws in many war-affected areas of the country and instead a variety of approaches to reclaiming land and property have been used - from violence, to attempts at applying tribal and/or Islamic law, or components of state lawall of which are often variously backed up by militia enforcement. ${ }^{74}$ Some Iraqi lawmakers argue that Order 101 and Law 20 should be merged to more effectively address the ISIS-era conflict dislocations, while others note that there are important situations relating to the ISIS conflict that are not covered by either law. ${ }^{75}$ One of the more important of these is that ISIS took many land, property and identification documents away from citizens and burned them while issuing their own, so as to gain greater control over areas they occupied. This included redistributing land and

68 D. Isser \& P. van der Auweraert, Land, Property and the Challenge of Return for Iraq's Displaced (Washington DC, US Institute of Peace Special Report 221, 2009).

${ }^{69}$ Republic of Iraq, Decree Number 262 of 2008 (Baghdad: General Secretariat for the Council of Ministers, 2008).

70 Government of Iraq, Order 101/S (Baghdad: Republic of Iraq, Prime Minister's Office, 2008).

71 D. Stigall, Refugees and Legal Reform in Iraq: The Iraqi Civil Code, International Standards for the Treatment of Displaced Persons, and the Art of Attainable Solutions (Amman: US Institute of Peace on Housing, Land and Property Rights in Iraq, 2009).

72 Author interviews with Iraqi lawmakers, Iraqi NGO, Kurdish government official, October 2016, November 2017.

73 Household survey of 110 IDPs conducted by the NGO Social Inquiry for the Author's research team, in July 2017.

74 Author interviews with researchers in Iraq, personnel from the UN community policing program, Iraqi NGO, October 2016, July and November 2017.

75 Author interviews with Iraqi lawmakers, October, 2016. 
property to whom they wished. ${ }^{76}$ The result is that providing evidence of pre-ISIS ownership and occupation can be extremely difficult under the law.

Both special processes suffer from lack of awareness on the part of dislocated populations. Recent research with IDPs in northern Iraq reveal that 63 percent were unaware of any government laws pertaining to land and property returns, half do not believe the government will assist with returns, and only 13 percent had heard of the IPCC. ${ }^{77}$ For the current period of dislocation and returns connected to the ISIS occupation and conflict (2014 to present) there are no legal or institutional mechanisms by which to reclaim lands and properties, other than the vague Decree 262 and Order 101.

\section{Conclusions}

The current land and property conflict situation in Iraq intertwines three broad historical-topresent scenarios. First are the many events by which dispossession has taken place over timeforced dislocations, property abandonment, confiscations, distress and duress sales, fraudulent documents, transfers and inheritance conflicts, abuse of certain laws, land reforms - and which are followed by multiple good faith sales and purchases which act to solidify dispossessions. This is complicated by the process of reclaiming the same lands by individuals and groups dispossessed in different time periods. Second, the changing laws and sequence of legal sources that combine tribal, Islamic, customary and statutory (Egyptian, French, Ottoman, Ba'athist, postBa'athist) laws results in confusion, contradiction and misapplication. This occurs when older laws are not rescinded as new laws are intended to supersede them, and when tribal, Islamic or customary law contradicts statutory law and each other. Third, the different ideologies of government that has produced different laws for different purposes greatly affects the current governance of land and property.

In this context the lack of specific legislation and institutions that are able to attend to the dislocations and effective return from the ISIS war constitute real concern. The more than 3 million IDPs that resulted from ISIS occupation of cities, towns and rural areas in Iraq is a significant population, and without a robust, tailored legislative and institutional restitution effort operating in a transitional justice context to support their return and reintegration —well apart from the existing Property Claims Commission, the risk is that returnees will default to armed kin to solve land and property disputes. ${ }^{78}$ What is needed is legislation authorizing a land and property restitution process that takes into account lessons learned from the previous two special processes whereby a land commission can operate (apart from normal courts) to handle claims within international standards, move with sufficient speed, and provide realistic remedies. While the legislative component needs to be Iraqi law, international law and standards can contribute as they do for restitution processes in other countries in a transitional justice approach. A significant advantage to a special process set apart from and prevailing over other Iraqi laws and institutions (in a transitional justice format) is an ability to temporarily relax certain evidence rules for land

\footnotetext{
76 Author interviews with IDPs and Iraqi NGOs; a household Household survey of 110 IDPs conducted by the NGO Social Inquiry for the Author's research team, in July 2017.

77 Household survey of 110 IDPs conducted by the NGO Social Inquiry for the Author's research team, in July 2017.

78 Author interviews with Iraqi lawmakers. Erbil Iraq, October 2016.
} 
and property claims regarding the supremacy of the document, in order to allow other forms of corroborative evidence into claims and dispute resolution proceedings. A very wide variety of mass claims evidentiary techniques are available which have been successfully used in other war-affected land and property rights scenarios that could be helpful in this regard. ${ }^{79}$

While all war-affected land and property restitution processes are complicated and manifest difficulties, much has been learned from past successes. Particularly important is the great utility of a deep legal history that is widely respected by the affected population, which is a significant advantage and opportunity in the case of Iraq. As parts of the international community now pledge $\$ 30$ billion to assist the country with reconstruction ${ }^{80}$ this legal history needs to be put to good use in resolving Iraq's many and complicated land and property problems.

79 For a review see J. Haersolte-van Hof, 'Innovations to speed mass claims: new standards of proof, in, Permanent Court of Arbitration (ed.), Redressing Injustices Through Mass Claims Processes, pp. 13-24 (Oxford: Oxford University Press. 2006); H. Holtzmann \& E. Kristjansdottir, International Mass Claims Processes: Legal and Practical Perspectives - Remedies (Oxford: Oxford University Press, 2007).

80 E. Graham-Harrison, 'Donor conference pledges $\$ 30$ bn to help Iraq rebuild after ISIS, The Guardian, February $15,2018$. 